\title{
Study of Phenomenology in Female Football Fans, Persib Bandung Club
}

\author{
Windi Fitriyani ${ }^{1}$, Oky Oxcygentri, ${ }^{2}$ Nurkinan $^{3 *}$ \\ ${ }^{1,2,3}$ University of Singaperbangsa Karawang \\ Email: ${ }^{1}$ windif0@gmail.com, ${ }^{2}$ mickey.oxcygentri@fisip.unsika.ac.id, ${ }^{3}$ nurkinan59@gmail.com \\ *corresponding author
}

Keywords:

football fans, motive

\begin{abstract}
Many are involved in football, including football supporters. Supporters are the people who provide support in a football match. Today, the stadium is dominated not only by men but many women, which relates to the motives of female fans of Persib Bandung football club. This research aims to find out the experiences, explanations, and meanings of women fans of Persib Bandung football club. The method used in this study is a qualitative method with a phenomenological approach. Based on the research results, it can be concluded that the motives of women fans of Persib Bandung football club have two categories. Which are motive cause consisting of Geographical Location Motive and Popularity Level Motive While the motive of hope (in order to motive) or the motive of the destination, namely: Motive of Support Directly In the Stadium, Entertainment Motif, and Motive of Got A Partner.
\end{abstract}

Copyright (C) 2021 Channel Jurnal Komunikasi. All right reserved.

\section{INTRODUCTION}

Football cannot be separated from supporters. Therefore, supporters can be said to be the 12th player in a team because supporters cannot be separated from football. From small competitions to world-level competitions, supporters' role is needed because it can give a sense of enthusiasm to the players. Supporters are an expression of the pride and love of the football team supporters. Each soccer team has a group of supporters, both male and female supporters. Between male supporters and female supporters, supporter names are also different. For example, Viking Persib Club (the name for male supporters of Persib Bandung) and Ladies Vikers / Viking Girls (the name for female supporters of Persib Bandung).

Because football is still considered a masculine sport, to show women's identity who tend to feminism, a different name is embedded. Usually added with the appendage "ta", which indicates "woman", "miss", "lady", "girl", and so on. Like, Viking Girls, Jak Angel, Aremanita, and many others. The aim is to confirm that the member of the supporters has a female identity.

Based on the research of The Nielsen Company shows the case in England where based on a survey conducted by Sir Norman Chester Center for Football Research shows that the number of female supporters made up 12\% of the total supporters of the League Premiere and continued to increase by $15 \%$ in 2002. Based on Nielsen data in 2013, the increase is significantly of female supporters to be $32 \%$, which means that there has been a shift in behavior among female consumers who have started came to the stadium to watch a football match (Kusuma 2016).

Initially, the existence of women in Persib Bandung's support was still individual after many of them formed their first name, namely Ladies Vikers. Still, at that time, their existence was not well organized, nor did membership administration exist. Unlike today, the Ladies Vikers group is now known and spread across every area of West Java. Until finally entered and understood by the people of Karawang.

Ladies Vikers is a supporter group for the football team from Bandung, namely Persib Bandung, which consists of women. The meaning of the name Ladies Vikers is Viking Girls. This group's founding stems from often gathering together to support the same football club and having a similar hobby, namely watching the Persib Bandung football match. Ladies Vikers Karawang is a forum for women who like soccer matches and support the same club, Persib Bandung.

Indonesian football fans over time, although men still dominate. However, the presence of women in the stadium is familiar. Almost all soccer supporters in Indonesia must have a supporter group consisting of women. They do not just watch, and they do not hesitate to sing chants of support for their proud team. 
The reason for researching this phenomenon, namely the motives of women fans of the Persib Bandung football club, because currently many women have joined the community or football supporter group with one of them is Ladies Vikers Karawang. This study aims to determine and understand the motives of female fans of football club Persib Bandung.

\section{LITERATURE REVIEW}

\section{A. Alfred Schutz's Theory of Phenomenology}

According to Stephen W. Littlejohn and Karen A. Foss, phenomenology assumes that people actively interpret their experiences and understand the world with their personal experiences (Pertiwi, 2019).

Phenomenology is the science that discusses an event (phenomenon). The science of events can be the science that examines what appears to be the science that discusses what appears to the subject's experience. Because basically, there are no events that are not experienced (Adian 2010).

In Schutz's view, humans are social creatures, so that awareness of everyday life in the world. Humans are expected to understand each other and act in the same way. We get feedback on shared experiences, and it is from the type that humans can indulge in the wide world, and it is ourselves who play a role in a typical (Kuswarno 2009).

Schutz argues that the everyday social world is always an intersubjective and meaningful experience. Thus, individuals' phenomenon reflects transcendental experiences and understanding (verstehen) about meaning (Farid 2018).

The gist of Schutzes opinion is how we understand social ac by interpretation. The process of interpretation is used to clarify the meaning, to provide an implicit concept. In other words, the basis of social action refers to experience, meaning, and awareness (Kuswarno 2009).

The basic premise used in phenomenological research is that an event will have meaning for those who experience it directly. Mediated individual experiences mediate mediated scientific understanding experience is derived from the structure of that experience and not constructed by researchers (Kuswarno, 2009).

Schutz agrees with Weber's argument that social phenomena in their ideal form must be properly understood. Schutz also accepts Weber's opinion and even emphasizes that social science is essentially interested in social action. The concept of "social" is defined as a relationship between two or more people. In contrast, the concept of "action" is defined as a relationship between behaviors that make individual meaning (subject meaning). However, according to Schutz, subjective meaning does not exist in the individual world alone. The subjective meaning that is formed in the social world is caused by actors who have the same "similarities" and "togetherness" (standard and shared) among the actors. Therefore, the subjective meaning is called "intersubjective" (Kuswarno, 2009).

Schutz then explains that if we look to the future (looking forward to the end) is a fundamental condition for the concept of action or action. Action is an attitude directed to create in the future that has been determined (determinate). The sentence contains the meaning that a person has a past (pastness). Thus the purpose of action has elements to the future (futurity) and elements to the past (pastness) (Kuswarno, 2009).

It is necessary to give a phase to describe someone's actual actions. The phase is in-order-to motive action (UmZu-Motiv), which states in the future; and because-motive action (Weil-Motiv), which states in the past (Kuswarno, 2009).

As a researcher, we see that the number of cases of female football fans in Indonesia, even globally, continues to rise from time to time. The rising number creates a new phenomenon in the community because football was synonymous with men. However, this phenomenon is unique because it is carried out in a conscious state and produces a deliberate action.

\section{B. Women}

The term woman in the Big Indonesian Dictionary means a woman or person (human) who can menstruate, become pregnant, bear children, and breastfeeding. Talks about women in the past revolved around depicting physical and moral beauty only, then after that, it would be said that women have to bear children, cook, and dress. Therefore, women are considered family members who only take care of back affairs, not appear in front. No matter how much money one gets, one will never be considered the breadwinner (Nurulmi 2017).

Biologically from a physical point of view, women are distinguished by being smaller than men, having a smoother voice, women's body development occurs earlier, women's strength is not as muscular as men's, and so on. Women have a calm demeanor. Women's feelings cry more quickly and even less when they face serious problems. Meanwhile, Kartini Kartono said that the physiological differences experienced since birth were generally strengthened by the existing cultural structures, particularly by customs, socio-economic systems, and the influence of education. (Pertiwi, 2019: 48).

Women, Ladies Vikers, being soccer supporters do not prohibit women from channeling their hobbies like men. Many women out there are afraid to join the football supporter community, but not for this Ladies Vikers member. For her, it is something fun. 


\section{Fans}

Fan came from the Latin word fanaticus, which meanbeingbe crazy about something but inspiring that ultimately produces inspiration. A fan is a person who likes something enthusiastically (Dhanny 2018).

\section{Community}

According to Iriantara, a community is a group of individuals who live in a particular location and are usually related to the same interests. Meanwhile, according to Wenger, a community is a group of people who share problems, concerns, or interests on a topic and deepen their knowledge and expertise by interacting with each other continuously (Aditya 2016).

\section{E. Football}

Football is a game in teams, consisting of a team of 11, including a goalkeeper. Football is a team game in which each team must put the ball into the opponent's goal as much as possible but at the same time protect their own goal from the attack of the opposing team, the team that puts the most balls into the opposing team wins (Putra 2017)

Football supporters usually have various ways of supporting their team during the competition. The supporting action can be singing aloud (chants), shouting motivational sentences, and often shouting curses to the opposing team as a form of support for their favorite team (Nasution 2017).

\section{F. Persib Bandung}

Persib Bandung is an Indonesian football club formed on March 14, 1933, originating from Bandung, West Java. Before the formation of Persib, in 1923 the Bandoengsche Indonesische Voetbal Bond (BIVB) was established. Then BIVB disappeared, and two new clubs were formed, namely the Indonesian Football Association Bandung (PSIB) and the National Voetball Bond (NVB). Furthermore, on March 14, 1933, the two clubs decided to merge, and a new club named Persib was established; at that time, Anwar St. Pamoentjak serves as the first chairman (Kristanto 2016).

\section{METHOD}

The method used in this research is qualitative with a phenomenological approach. In qualitative research, the usually used methods are interviews, observation, and document use (Moleong 2012). Data collection techniques in this study using in-depth interview techniques, observation, documentation, and literature study. Data analysis techniques are performed using data analysis techniques proposed by Miles and Huberman, including data reduction, data display, and conclusion drawing (Sugiyono 2009).

Purposive sampling and snowball sampling techniques were used to determine informants in this study. In other words, the researcher chooses informants who are related to each other but still following the provisions of the informants that have been made. There were five people in this study, as follows:

Table 1. Participants Identity

\begin{tabular}{clcl}
\hline No & Initial of Informant & Age & How Long be a fan \\
\hline 1. & DK & 25 & 19 years \\
\hline 2. & SM & 25 & 9 years \\
\hline 3. & TN & 20 & 7 years \\
\hline 4. & GO & 35 & 14 years \\
\hline 5. & LN & 25 & 10 years \\
\hline 6. & Kania Aprilia Pratiwi & 25 & 10 years \\
\hline
\end{tabular}

\section{RESULTS, AND DISCUSSION}

\section{A. Communication Experience of Women Fans of Persib Bandung Football Club}

Communication experience in this research is experienced by individuals and is related to communication aspects, including the processes, symbols, and meanings produced and their encouragement for action. According to Schutz, each person's experience at an object stage is different. Therefore experience is subjective, especially when taking actions and attitudes in everyday life (Kuswarno, 2009). Therefore, the experience of each individual is different, some have pleasant experiences and some have unpleasant experiences:

1. Fun Communication Experience for Women Fans of Persib Bandung Football Club

Experience is something that has been experienced, lived, or felt, whether it has been a long time or has 
happened long ago. Experience can not be separated from everyday life, and experience has a precious value for everyone. Meanwhile, a pleasant communication experience is an event that makes us feel happy. An enjoyable experience can be formed because someone who experiences an event feels the impression of feeling happy and happy.

2. Unhappy Communication Experience Women Fans of Persib Bandung Football Club

An unpleasant communication experience is experienced by someone but does not cause happiness to those who feel it, but sadness, distress, or disappointment.

Based on the research results on the pleasant communication experience for women fans of the Persib Bandung football club, namely, feeling happy or happy at the stadium. Feeling happy when Persib can win the match, feeling happy to meet Persib Bandung idol players, and adding relationships. or friends from out of town.

As for the unpleasant communication experience of women fans of the Persib Bandung football club, some informants have experienced disputes with other football clubs' supporters. Some sad experience events while witnessing a soccer match, such as having difficulty communicating while witnessing matches abroad, and some almost experience pickpocketing at the stadium. Moreover, what the Persib football club's female fans do not like the most is when they cannot watch Persib's match directly at the stadium. The experiences that each informant expressed were following the experiences they had previously experienced.

\section{Motives of Women Fans of Persib Bandung Football Club}

The motive shows a systematic relationship between a response or a set of responses with a particular impulse state. An explanation arises because there is a need or desire. A need can be seen as a lack of something, which makes immediate fulfillment to immediately balance this deficiency situation, functioning as a strength or need (Ahmadi 2007).

Researchers are trying to find out what motives underlie the actions of women who like the Persib Bandung football club because now it has become a separate phenomenon. A motive is an activator, reason, or impulse in a man that causes her to do something.

To describe a person's actions, Schutz grouped them into two motives, namely:

1. Because-motive (Weil-Motiv)

It means action refers to past motive-cause. A person must have reason in the past that drives her action.

2. In-order-to-motive (Um-zu-Motiv)

It means an action that refers to the future, or (hope-motive), which explains that if someone does an activity, they will have a goal to be achieved (Kuswarno 2009).

From the interviews conducted by researchers with several informants who are female fans of the Persib Bandung football club, the motive of the cause (because motive) or past motives are actions that someone does for reasons in his past. They like Persib Bandung because of its geographical location and level of popularity. They love and support them because they are in the same area and are more popular than other football clubs.

Have a goal to be achieved. The motive for the hopes of women fans of the Persib Bandung football club is to always support their proud club directly by witnessing in the stadium, as entertainment because they do not have to watch the match at home while resting. Furthermore, the motive for the next hope of being able to find a partner or mate is equally fond of Persib Bandung.

\section{Self Meaning of Women Fans of Persib Bandung Football Club}

The concept of meaning has attracted communication, psychology, sociology, anthropology, and linguistics. That is why some communication experts often mention the word meaning when they formulate a definition of communication. According to Stewart L. Tubbs and Sylvia Moss, as quoted by Alex Sobur, for example, communication is a process of forming meaning between two or more people. Then Judy C. Pearson and Paul E. Nelson, who Alex Sobur also quoted, said that communication is a process of understanding and sharing meaning (Sobur 2003).

The essence of Schutz's opinion is how we understand social action by interpretation. The interpretive process is used to clarify the meaning so that it can provide an implied concept. In other words, the basis of social action refers to experience, meaning, and awareness (Kuswarno 2009).

Humans in general and female fans of Persib Bandung in Karawang, especially those studied by researchers, tend to give meaning to what they are experiencing or have experienced. The results of data carried out by conducting interviews with informants produce several different self-meanings from each informant. The definition generated from these informants is based on experience and is also interpreted differently by each informant. 
1. Tomboi (the girls look like a boy) As a football club fan, she feels a tomboi because she is comfortable in that environment and likes soccer. She feels comfortable in an environment where the majority of men. She even thinks that she is more courageous than other women who usually feel afraid of being in a male environment. Because it is a necessity, so she feels comfortable and happy without feeling worried or threatened.

2. Loyal fans

Loyal fans are people who consistently provide support, encouragement, or support in various forms and situations. Meanwhile, according to KBBI (Big Indonesian Dictionary), supporters are people who consistently provide support. Moreover, being loyal, according to the KBBI, is upholding stance and promises. A devoted fan, he will not leave Persib anytime and anywhere. Win or lose, they will always support Persib.

3. Different From Others

From some people, there may be some people who feel like being different from others. Still, many people rarely do this Because usually, other people will do the same thing with other people, so that ordinary words will arise. What is meant by different here is Not different negatively, but she wants to prove that she can do what she wants, not because of someone else's invitation.

4. Advisor

An advisor is a person who gives advice or suggestions. In conveying direction, the person must use a good way because if not good, the person providing the guidance will not accept it can cause a dispute between the two parties. The responsibility of an advisor is quite heavy, as it must ensure its members are well behaved. Furthermore, if one of the members is in trouble, the counselor should also be responsible.

5. Be Herself

Being herself is not just accepting one's weaknesses or strengths. So is someone must be accompanied by efforts to improve weaknesses and maintain strengths. If it is not accompanied by effort, it is the same as not understanding ourselves.

\section{CONCLUSION}

The communication experience experienced by female fans of the Persib Bandung football club consists of pleasant experiences and unpleasant experiences. The informants experienced this experience through previous experiences.

The motive of women fans of the Persib Bandung football club is influenced by the motive of cause (because of motive) and motive of hope (to motive). Because motive is the background or reason for female fans of the Persib Bandung football club because of the geographic location and popularity level motives. While the motive of hope (to motive) or the motive for the future goals, namely: Direct Support Motives at the Stadium, Entertainment Motives, and Motives to Get a Partner.

Women fans of Persib Bandung club behave and behave as Ladies, interpret themselves, among others: Tomboi, Loyal Fans, Different From Others, Advisors, and Being Her Self. The meaning conveyed by the informants has gone through a process of sensing and experiences.

\section{REFERENCES}

[1] Adian, Donny Gahral. (2010). Pengantar Fenomenologi. Depok: KoeKosan.

[2] Aditya, Ardiansyah Prima. (2016). "Komunikasi Kelompok Pada Komunitas Instameet Dalam Meningkatkan Kemampuan Fotografi Anggota.” Lampung. http:/digilib.unila. ac.id/24524/3/SKRIPSI TANPA BAB PEMBAHASAN.pdf.

[3] Ahmadi, Abu. (2007). Psikologi Sosial. Jakarta: Rineka Cipta.

[4] Dhanny, Ayu Ika. (2018). “Analisis Motivasi Penggemar Korean Pop Dalam Membeli Replika Pakaian Dan Aksesoris Di Online Shop Instagram.” Lampung. https://fdokumen.com/document/analisis-motivasi-penggemarkorean-pop-dalam-tanpa-bab-pembahasanpdf-memiliki.html.

[5] Farid, Muhammad. (2018). Fenomenologi Dalam Penelitian Ilmu Sosial. Jakarta: Kencana. Kristanto, Arif Budi. (2016). "Sejarah Singkat Persib Bandung Dari Masa Ke Masa.” Pikiran Rakyat. diakses dari https://www.pikiranrakyat.com/persib/pr-01252694/sejarah-singkat-persib-bandung-dari-masa-ke-masa.

[6] Kusuma, Yoseph Benny. (2016). “Analisis Perilaku Pendukung Wanita Klub Sepakbola Di Indonesia.” 26 No. 3 : 1-22. http://dx.doi.org/10.20473/jeba.V26I32016.\%25p .

[7] Kuswarno, Engkus. (2009). Fenomenologi: Metodologi Penelitian Komunikasi: Konsepsi, Pedoman, dan Contoh Penelitian. Bandung: Widya Padjadjaran.

[8] Moleong, Lexy J. (2012). Metodologi Penelitian Kualitatif. Bandung: PT Remaja Rosdakarya.

[9] Nasution, Fajrin Febrian. (2017). "Suporter Sepakbola (Studi Etnografi Mengenai Fanatisme Suporter 
Di Kota Medan)." Universitas Sumatera Utara. http://repositori.usu.ac.id/bitstream/ handle/123456789/2468/120905051.pdf?sequence=1\&isA llowed=y.

[10] Nurulmi. (2017). "Peran Perempuan Dalam Penigkatan Kesejahteraan Keluarga Petani Di Desa Padangloang Kecamatan Patampanua Kabupaten Pinrang.,

[11] Pertiwi, Syam Eka. (2019). “Makna Identitas Diri Anggota Komunitas Motor „Molek” Bagi Perempuan Di Karawang.” Universitas Singaperbangsa Karawang.

[12] Putra, Galank Riza Arya. (2017). "Survei Keterampilan Dasar Bermain Sepak Bola Siswa Putera Usia 10-12 Tahun Di SD Muhammadiyah Siraman.” Universitas Negeri Yogyakarta. https://eprints.uny.ac.id/47465/1/Galank Riza AP \%2812601244087\%29 -Skripsi.pdf.

[13] Sobur, Alex. (2003). Semiotika Komunikasi. Bandung: PT Remaja Rosdakarya.

[14] Sugiyono. (2009). Metode Penelitian Kuantitatif, Kualitatif Dan R\&D. Bandung: Alfabeta. 